\title{
Do Consumers Pay More Using Debit Cards than Cash
}

\author{
Runnemark, Emma; Hedman, Jonas; Xiao, Xiao
}

Document Version

Accepted author manuscript

Published in:

Electronic Commerce Research and Applications

DOI:

10.1016/j.elerap.2015.03.002

Publication date:

2015

\section{License \\ CC BY-NC-ND}

Citation for published version (APA):

Runnemark, E., Hedman, J., \& Xiao, X. (2015). Do Consumers Pay More Using Debit Cards than Cash.

Electronic Commerce Research and Applications, 14(5), 285-291. https://doi.org/10.1016/j.elerap.2015.03.002

Link to publication in CBS Research Portal

\section{General rights}

Copyright and moral rights for the publications made accessible in the public portal are retained by the authors and/or other copyright owners and it is a condition of accessing publications that users recognise and abide by the legal requirements associated with these rights.

Take down policy

If you believe that this document breaches copyright please contact us (research.lib@cbs.dk) providing details, and we will remove access to the work immediately and investigate your claim. 


\section{Do Consumers Pay More Using Debit Cards than Cash Emma Runnemark, Jonas Hedman, and Kiao Kiao}

Journal article (Post print version)

CITE: Do Consumers Pay More Using Debit Cards than Cash. / Runnemark, Emma; Hedman, Jonas; Xiao, Xiao. In: Electronic Commerce Research and Applications, Vol. 14, №. 5, 2015, p. 285-291.

00I: 10.1016/j.elerap.2015.03.002

Uploaded to Research@CBS: December २016

(C) 2016. This manuscript version is made available under the CC-BY-NC-ND 4.0 license http://creativecommons.org/licenses/by-nc-nd/4.0/

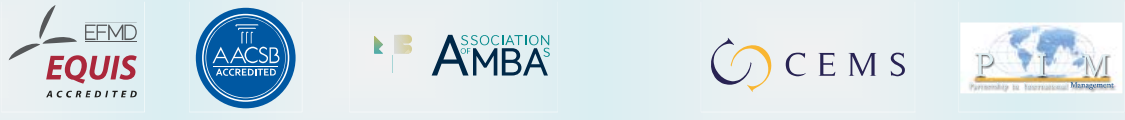




\title{
Do Consumers Pay More Using Debit Cards than Cash?
}

\author{
Emma Runnemark ${ }^{\mathrm{a}}$, Jonas Hedman ${ }^{\mathrm{b}}, \mathrm{Xiao}^{\mathrm{Xiao}}{ }^{\mathrm{c}}$ \\ a This paper is dedicated to the memory of Emma Runnemark, good colleague \\ and dear friend \\ ${ }^{\mathrm{b}}$ Corresponding author. Department of IT Management, Copenhagen Business \\ School, Howitzvej 60, DK-2000, Copenhagen, Denmark. Email address: \\ jh.itm@cbs.dk. \\ c Department of IT Management, Copenhagen Business School, Howitzvej 60, \\ DK-2000, Copenhagen, Denmark. Email address: xx.itm@cbs.dk.
}

\begin{abstract}
We conduct an incentivized experiment to study the effect of the payment method on spending. We find that the willingness to pay is higher when subjects pay with debit cards compared to cash. The result is robust to controlling for cash-on-hand constraints, spending type, price familiarity and consumption habits of the products. The evidence thus suggests that different representations of money matters for consumer behavior. Such results further tease out the underlying mechanism of how payment methods influence spending behavior, which poses important implications for both consumers and merchants, as well as designing of digitalized payment in the future. .
\end{abstract}

Key words: payment methods; debit cards; cash; willingness-to-pay; experiment

Acknowledgements: The authors are grateful for financial support from Copenhagen Finance and IT Region and the Danish Enterprise and Construction Authority grant number ERDFH09-0026. We thank Erik Wengström, participants at the Copenhagen University lunch seminar, the 5th workshop of Copenhagen Network of Experimental Economists, and the 9th Nordic Conference on Behavioral and Experimental Economics for helpful comments. Emma Runnemark is also grateful for support from the Swedish Wholesale and Retail Development Council. 


\section{Introduction}

Payments are deeply embedded in our daily life. Every day, we carry out various payments in different contexts and with different methods. For most part of the 1900s, cash and checks were the most common exchange means available for purchases and financial transactions between people and organizations (Evans and Schmalensee, 2005). During the second half of 1900s, payment cards, such as credit and debit card, were made available for store purchases and later used to withdraw cash from Automatic Teller Machines (ATMs) (Slawsky and Zafar, 2005). In the 1990s, electronic commerce appeared as an alternative way of conducting financial transactions over the Internet and internet payments and internet banks emerged (Zwass, 1996). Now the focus has shifted to the mobile phone and its capabilities of being a payment device. The prediction is that sooner or later, cash will die out and we will have a cashless society (Arvidsson and Markendahl, 2014; Carton and Hedman, 2013; Hedman, 2012).

Similar to payment practices that involve multiple industries (e.g., banking, retailing, and IT), payment research is a multi-disciplinary area that is tackled by scholars from Information systems who are mostly interested in adoption and diffusion of digital payment technologies (Dahlberg et al., 2008; Holmström and Stalder, 2001; Jonker, 2007; Mallat, 2007; Ondrus and Pigneur, 2006; Plouffe et al., 2001; Schierz et al., 2010; Xin et al., forthcomming), scholars from economics who are mostly concerned with payment patterns at a macro level (Garcia-Swartz et al., 2006; Garcia-Swartz et al., 2004; Humphrey, 2004, 2010; Prelec and Loewenstein, 1998), scholars from psychology striving to understand how payment context (e.g., recipients, pricing mechanism) affects paying behavior (Gneezy et al., 2010; Jung et al.; Menon et al., 1997; Srivastava and Raghubir, 2002), and finally scholars from consumer research and marketing who are interested in how different payment methods 
influence consumers’ spending behavior (Chatterjee and Rose, 2012; Hirschman, 1979; Raghubir, 2006; Raghubir and Srivastava, 2002, 2009; Thomas et al., 2011).

This last stream of research on payment outcomes has attracted most attention in the payment area, and hence generated fruitful results with important implications for designing new payment methods, which is deemed as part of the wide spread digitalization phenomenon. The results of these studies have challenged the assumptions of standard economic theory that consumer valuations of products and services are independent of how money is represented, i.e. the payment instrument, supported by the evidences that the payment instrument itself does affect spending (Feinberg, 1986; Hirschman, 1982; Prelec and Simester, 2001; Raghubir and Srivastava, 2008; Soman, 2001; Soman, 2003). However, it is worth noting that studies in this field have mainly been concerned with the comparison between credit cards and cash, showing that people tend to pay more with credit card (Hafalir and Loewenstein, 2009; Humphrey, 2004; Prelec and Simester, 2001). Considering the fact that credit cards and cash differ on two fundamental aspects (the coupling between consumption and payment, and the format), it is reasonable to conclude that such impacts can be attributed to 1) the temporal separation between consumption and payment (Prelec and Loewenstein, 1998), or 2) the representation of money itself (Feinberg, 1986; Raghubir and Srivastava, 2008), or 3) a combination of both. One way to tease out the underlying mechanism of why certain payment methods induce more spending (or willingness to spend more) is to find a substitute payment method for cash that only differs in terms of the format/representation. Other studies in this endeavor focus on gift certificates, pre-paid cards, and different denominations of cash (Mishra et al., 2006; Raghubir and Srivastava, 2008; Raghubir and Srivastava, 2009; Soman, 2001; Soman, 2003; Vandoros, 2013) but apart from cash denominations, these payment methods are often restricted to certain purchases so they may not be treated as substitutes for cash (see Felső and Soetevent, 2014). 
This research serves as an effort to further clarify the underlying mechanism of the relationship between payment methods and spending behavior by investigating whether consumers pay more for identical products using debit cards compared to cash. There are three reasons for comparing cash and debit cards. First, debit cards are attractive to study since debit card transactions, just as cash, are ubiquitous and immediate, making debit cards a suitable substitute for cash. In other words, debits cards don't differ from cash in terms of the underlying payment mechanism (e.g., tight coupling between consumption and payment), but only in the representation of money (digital/invisible versus physical). In this sense, comparing debit cards with cash will allow us examine whether payment format itself would influence the spending behavior. This is indeed an under-explored research area. Second, debit cards have become increasingly popular (Borzekowski et al., 2008). For instance, debit card transactions account for a larger share of payments in the US than credit cards (CPSS, 2013). In Denmark, where we conduct our experiment, debit cards are the most common payment method both in terms of transaction value and diffusion rate (87 percent of the population between 15-79 years old has the national debit card Dankort) (Nationalbanken, 2014). Third, debit cards are increasingly being embedded on mobile phones and thus the affect of debit cards on spending is critical for mobile payment research.

Our experiment is among the first endeavors to compare debit card spending with cash. Indirect evidence can be traced to charitable giving where Soetevent (2011) finds using a field experiment that conditional on choosing to donate money, debit cards lead to higher donations than cash. However, just as in the incentivized experiments on credit cards, there is the possibility that the result is, at least partly, driven by cash-on-hand constraints. To tease out the influence of the payment form, our experimental design controls for this as well as order effects, spending type, price familiarity and consumption habits of the products. 
We find that the willingness-to-pay is higher for debit cards than cash. The effect is sizeable, average bids increase by 22 to 54 percent when paying with debit card. This result suggests that the format of money affects the willingness to pay. Cash payments, which are more transparent than debit card transactions, make it easier to control spending and this effect is not solely due to cash-on-hand constraints. This could explain why some people prefer cash in order to control their spending's. The implication for consumers, with the ongoing digitization of payments, is that they lose some control over their spending and face the risk of overspending. For merchants, on the other hand the recommendation is to encourage debit card payment.

The paper is organized as follows. The next section reviews the related literature on debit cards and cash spending. Section 3 outlines the experimental design, procedure and the expected outcomes. In section 4 we present the results. This is followed by a discussion in section 5. Finally, we conclude the paper in section 6.

\section{Payment Method and Spending}

Studies focusing on how different payment methods induce different spending behavior of the consumers have been one of the main streams of payment related research for in particular marketing and consumer research. Credit cards are among the most studied payment methods (Carow and Staten, 1999; Feinberg, 1986; Hafalir and Loewenstein, 2009; Humphrey, 2004; Thomas et al., 2011; Worthington et al., 2007; Zinman, 2009) and used to be compared with cash. One of the earliest efforts was carried out by Prelec and Simester (2001) who conduct two incentivized experiments comparing credit cards with cash by selling sports tickets and a dinner certificate. They find a difference between those who are instructed to pay with their credit cards and those who are instructed to pay with cash for the sports tickets but not for the dinner certificate. While there are other differences between the two 
studies, an important difference is that the sports tickets are of an uncertain price and the dinner certificate states how much it is worth at the restaurant. They also vary exposure to credit cards among cash payers for the dinner certificate but do not replicate the logo effect. Thus, their results suggest that the payment method itself matters and that uncertainty regarding the price of the product may influence the outcome. Meanwhile, studies conducted in other controlled environment utilizing experiments are able to confirm the effects of the subjectivity associated with payment methods, in particular the forms, and found that the presence of a credit card logo only can induce higher willingness of paying (Feinberg, 1986; Raghubir and Srivastava, 2008). In another vein, Chatterjee and Rose (2012) find that credit cards seem to prime consumers to think about benefits of products while cash activate costs considerations. They suggest that since credit cards separate payment (and thus the pain of paying) from consumption, repeated use of credit cards reinforces the positive feelings of purchases while the immediate pain felt with cash reinforces cost considerations.

Furthermore, studies based on natural settings also present a similar pattern regarding spending behavior associated with different payment methods. For instance, research based on grocery data suggest that credit cards are associated with higher spending than cash, especially regarding certain types of products, such as flexible items (treats and luxuries) (Soman, 2003), and unhealthy foods (Thomas et al., 2011), suggesting cash constraining impulsive buying. Similarly, Hafalir and Loewenstein (2009) run a field experiment comparing cash and credit card spending at lunch time at a major insurance company. They find that only credit card users who are not carrying any credit card debt (convenience users) spend more than cash users, suggesting an effect from past credit card expenses.

The concept of “pain of paying,” advanced by Prelec and Loewenstein (1998), has been argued as the theoretical explanation for why spending may be higher with different payment instruments than with cash. The pain of paying idea suggests that when paying for 
consumption, consumers experience an immediate pain when parting with money. The less transparent the payment is (the less the payer feels the outflow of money), the less painful it is to pay. Soman (2003) defines the transparency of a payment method as the salience of parting with money. The level of transparency can be affected by the form that the payment comes in and the temporal separation of consumption and payment, and therefore people feel less pain when they don't see physical money going away, and/or when they know payment will only happen later, both features associated with credit cards, making it one of the least transparent payment methods (Raghubir and Srivastava, 2008). Furthermore, the fact that payment coupling and physical format of the payment influences spending behavior has also been tested and confirmed with other payment methods such as gift certificates, pre-paid cards, and checks (Raghubir and Srivastava, 2008; Raghubir and Srivastava, 2009; Soman, 2001; Soman, 2003).

On the other hand, this stream of research has rarely touched upon debit cards. The only existing evidence on whether debit cards incur higher spending than cash comes from a field experiment on charitable giving. ${ }^{1}$ Soetevent (2011) finds that conditional on choosing to donate money, debit cards lead to higher donations compared to cash. However only 9 percent of the approached households choose to donate money in the debit treatment, compared to 67 percent in the cash treatment, so the difference may be caused by household characteristics or that households are simply donating what loose change they have available. A propensity score matching estimator suggests that households with similar characteristics tend to donate more using debit card than cash but controlling for cash-on-hand constraints is not possible in this setting.

\footnotetext{
${ }^{1}$ Other aspects of debit cards, such as debit card adoption and substitution between debit and credit cards, are studied by, for example, Borzekowski et al. (2008), Hayashi and Klee (2003), Jonker (2007), and Zinman (2009).
} 
Studies on credit cards offer some further indication that debit cards may differ from cash and also suggest additional explanations for differences in spending. Debit and credit cards are similar in the salience of the physical form and the salience of the amount paid with the card (Soman, 2003). In addition, debit cards often come decorated with the same logos from payment service providers such as Visa and Mastercard. Feinberg (1986) uses a lab experiment showing that simply exposing students to the MasterCard logo and replicas of actual MasterCards increase cash donations to a charity. This logo effect suggests that, at least some elements of, the payment method may be associated with the level of spending. However, though also ranked low in transparency by Soman (2003), debit cards differ from credit cards on one important aspect - coupling of payment, which makes it a closer substitute for cash. Hence, it is of theoretical importance to compare debit cards with cash, so as to understand whether physical representation of money itself can influence people's spending behavior. In other words, the confounding effects of payment coupling, as is the case with credit cards, can be teased out from the effects of payment format, when the comparison between debit cards and cash is made.

\section{Does Willingness to Pay Differ Due to Payment Method?}

To test whether the willingness to pay for identical products differs between debit cards and cash, we sell three consumer products varying the payment method. To ensure that participants reveal their reservation prices, we use the Becker-DeGroot-Marschak mechanism (Becker et al., 1964), see also recent applications by, for instance, Prelec and Simester (2001) and Haws et al. (2012). We control for cash-on-hand constraints, order effects, spending type, price familiarity and consumption habits of the products, and we make immediate transactions using new payment technology. 


\subsection{Experimental Design}

We elicit willingness to pay for three consumer products using the Becker-DeGrootMarschak mechanism. For each product, participants make a bid. Then a participant's bid and a sale price is randomly drawn. If the selected participant's bid is higher or equal to the sale price, the bidder buys the product for the sale price. If the bidder's bid is lower than the sale price, there is no purchase and a new participant's bid and sale price is drawn until the product is sold. A participant with a successful bid will not partake in subsequent draws. To control for cash-on-hand constraints, we pay participants 100 DKK $(\approx \mathrm{US} \$ 15.5$ as of January 2015) at the beginning of the experiment. Bids are thus restricted to a maximum of 100 for each product. $^{2}$

The selected products are a clip card for ten beers at a student pub (cost 170), a clip card for six coffees from the full selection of coffees at a student café (cost 100), and a clip card for ten black coffees at the same café (cost 40). Both the student pub and the café are located in the participant pool's university building. To control for order effects (see e.g. (Kahneman and Knetsch, 1992), the order in which the products are presented to the participants vary in four ways always keeping the coffee items together.

\subsection{Procedure}

82 master level students (37 female, 45 male, average age 27) at the IT University in Copenhagen participated. The experiment lasted 30-40 minutes and was conducted during lecture time on April 4, 5 and 8, 2013. The participants had received an email in advance with some general information about the experiment including that everyone would receive 100 DKK for their participation and that they had to be silent during the experiment. No course

\footnotetext{
${ }^{2}$ All numbers henceforth refer to Danish crowns, DKK.
} 
credits were given. ${ }^{3}$ Though the choice of master students as the sample of the study has its limitations, it was deemed appropriate for the purpose of this study. We had to assure that the participants where able to make and receive payment with "relatively new and advanced" payment technology. In this case it was the iZettle ${ }^{4}$ and PayPal.

In all treatments, we first handed out receipt forms for the participation remuneration and gave the general instructions, orally and written, together with specific instructions for each treatment. In the cash treatment we informed the students that we would pay for their participation upfront in cash and we asked them to keep the 100 DKK banknote that they received on the desk in front of them. In the card/cash treatment we instead asked them to put the banknote in their pocket and to put their debit card on the desk in front of them as they would need it during the experiment. This was done to ensure that everyone had a debit card and that they would be exposed to the payment method. We also checked that all cards were debit cards when we handed out the money. ${ }^{5,}$,

The card/account treatment proceeded as the card/cash treatment but instead of paying the students in cash we informed them that we would transfer 100 DKK via PayPal using the email address that they wrote on the receipt. The money was transferred during the session to ensure that the students felt they had the money available to spend.

We then proceeded with the instructions for the auction. Before writing down their bids, the students answered control questions regarding the BDM mechanism, which we

\footnotetext{
${ }^{3}$ A short version of the instructions is available in Appendix A.1. Full instructions are available from the corresponding author.

${ }^{4}$ iZettle is a payment dongle that is plugged into any iPhone or Android based mobile phone. It converts the mobile into a payment card terminal.

${ }^{5}$ We ran the cash and the card/cash treatment simultaneously on April 4 and 8. We first divided the class into two groups. The cash treatment stayed in the classroom and the card/cash treatment was directed to another classroom. We used a manuscript to ensure that subjects received the same information in their respective treatments. For practical and administrative reasons, we did not divide the class for the card/account treatment. However, since the participating students belonged to the same study programs, but not the same course, we test for session effects using Wilcoxon-Mann-Whitney tests in the cash and card/cash treatments but do not find any differences.

${ }^{6}$ Five students could not participate in the card treatments as they did not have a debit card on them.
} 
corrected in public to ensure that everyone understood the BDM mechanism. After collecting the bid forms we made the draws to sell the products in front of the class. The students whose bids were successful paid the experimenter directly using cash in the cash treatment and using card via iZettle in the card treatments.

After the sale, we elicited how much the subjects thought each clip card cost. Paying one subject, randomly selected at the end of the experiment, 20 for each correct guess, incentivized this part. The students also rated themselves on the spendthrift-tightwad scale (Rick et al., 2008), which captures whether they feel that they have difficulty controlling spending or if they tend to hold on to tight to their money. The experiment ended with background questions including consumption habits for beer and coffee and payment habits.

\subsection{Expected Outcomes}

Our three treatments differ along two dimensions. First, we vary the payment method. In the cash treatment, the successful participants pay for the products using cash while in the card/cash treatment, they pay using debit card. Thus, if participants are willing to pay more for a product using debit card compared to cash, we should observe that bids are higher in the card/cash treatment. Second, we vary how we pay the 100 to the participants. In the card/account treatment, instead of paying the money in cash as in the card/cash treatment, we transfer it using PayPal.

The inclusion of the card/account treatment is for exploratory purposes since the expected outcome is ambiguous. To our knowledge there are no studies looking at the affect of account payments (whether done over on-line banking affects the willingness to pay), even though this is a very common method of payments. There are two important payment instruments, including direct debit and direct credit, underlying account payments (Kokkola, 2010). The main reason for including it is to learn whether simply showing cash depresses 
bids for card payers. If cash is associated with lower valuations then seeing the 100 available to spend in cash may decrease bids (Feinberg, 1986). In this case, we expect bids to be higher in card/account than in card/cash.

On the other hand, there might be an earmarking effect present. Studies show that, for example, contributions to taxes increase when these taxes are earmarked for specific purposes (Hundsdoerfer et al., 2011; Sælen and Kallbekken, 2011) and that child benefits are related to higher spending on child related products (Del Boca and Flinn, 1994; Kooreman, 2000)). In the cash and card/cash treatments, participants see the money available to spend in the experiment. In the card/account treatment the money never materializes but go directly into participants’ accounts. This may reduce the feeling of the money being earmarked for the experiment. In this case, we expect spending to be lower in card/account than in card/cash. Since cash-on-hand constraints are a concern in the Danish case, we did not include a cash/account treatment.

\section{Results}

We find the average of participants' bids for each of the three products and the average of the sum of the bids for each participant in Figure 1. The figure clearly shows that average bids are higher in the card/cash group than the cash group. Average bids are 36, 22, 52 and 37 percent higher in card/cash for beer, expensive coffee, coffee and the total respectively. Wilcoxon-Mann-Whitney tests show that coffee and the total are significantly higher in the card/cash group than in the cash group and weakly significantly higher for beer (two-sided, $n=53$, beer: $\mathrm{p}=0.086$, expensive coffee: $\mathrm{p}=0.173$; coffee: $\mathrm{p}=0.023$, total: $\mathrm{p}=0.035$ ). These findings suggest that payment form does matter for consumers' willingness to pay for products. 
Figure 1 further shows that bids for coffee are significantly lower in card/account than in card/cash and weakly significantly lower for beer and total which points to an earmarking effect (WMW, two-sided, $n=54$, beer: $p=0.083$, expensive coffee: $p=0.378$; coffee: $\mathrm{p}=0.019$, total: $\mathrm{p}=0.056$ ). In percent, average bids are 27, 14, 39 and 28 lower in card/account for beer, expensive coffee, coffee and the total respectively. There are no significant differences between cash and card/account (WMW, two-sided, n=57, beer: $\mathrm{p}=0.994$, expensive coffee: $\mathrm{p}=0.446$; coffee: $\mathrm{p}=0.923$, total: $\mathrm{p}=0.762$ ).

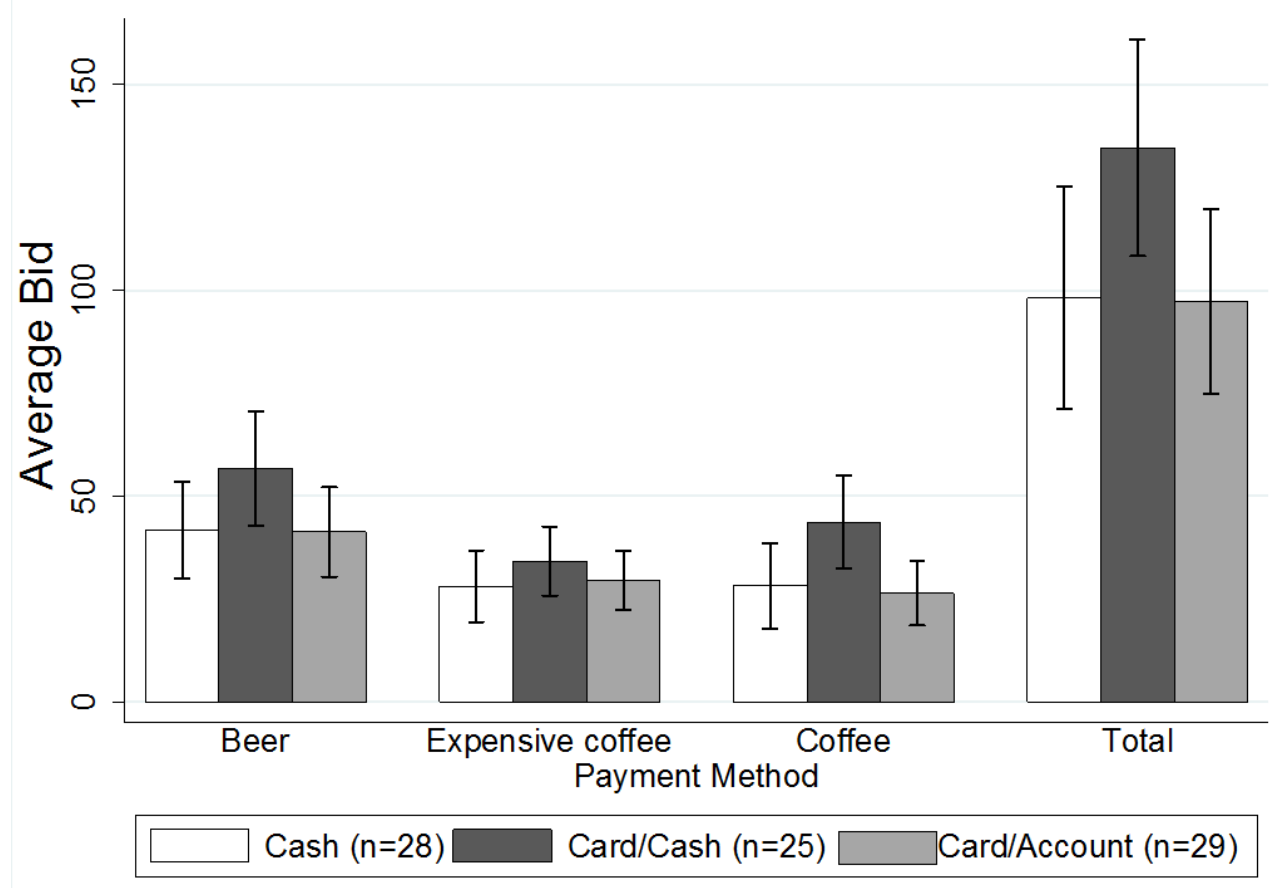

Fig. 1 Average bids in Cash, Card/Cash and Card/Account group

To control for additional factors that may affect bids, we provide SUR estimations in Table 1. This method produces more efficient estimates than single regressions when we have product specific variables and the regression errors are correlated for a given individual but not across individuals. The estimations show that the results remain and that they are stronger: 
bids are significantly higher in the card/cash group than in the cash group and significantly lower in the card/account group than in the card/cash group for beer and coffee.

Table 1 Regression Results

\begin{tabular}{|c|c|c|c|}
\hline & Beer & Expensive Coffee & Coffee \\
\hline Cash & $\begin{array}{c}-17.439 * * \\
(7.900)\end{array}$ & $\begin{array}{l}-1.281 \\
(6.205)\end{array}$ & $\begin{array}{c}-13.988^{* *} \\
(6.994)\end{array}$ \\
\hline Card/Account & $\begin{array}{c}-15.917^{* *} \\
(8.049)\end{array}$ & $\begin{array}{l}-1.625 \\
(5.612)\end{array}$ & $\begin{array}{c}-13.925 * * \\
(6.873)\end{array}$ \\
\hline Type & $\begin{array}{c}-1.884 * * \\
(0.865)\end{array}$ & $\begin{array}{c}0.125 \\
(0.657)\end{array}$ & $\begin{array}{l}-0.960 \\
(0.746)\end{array}$ \\
\hline Belief & $\begin{array}{l}-0.081 \\
(0.074)\end{array}$ & $\begin{array}{c}0.164 * * \\
(0.688)\end{array}$ & $\begin{array}{c}0.102 * * * \\
(0.040)\end{array}$ \\
\hline Consumption & $\begin{array}{c}0.111 \\
(0.647)\end{array}$ & $\begin{array}{c}0.541 \\
(1.231)\end{array}$ & $\begin{array}{c}0.644 \\
(1.580)\end{array}$ \\
\hline Constant & $\begin{array}{c}82.252 * * * \\
(21.673)\end{array}$ & $\begin{array}{c}11.749 \\
(13.536)\end{array}$ & $\begin{array}{r}31.820^{* *} \\
(13.172)\end{array}$ \\
\hline Order & YES & YES & YES \\
\hline No of obs. & 82 & 82 & 82 \\
\hline
\end{tabular}

There is also a small and negative effect of spending personality on beer bids, captured by the variable "Type”. It suggests that a participant who perceives she has difficulty in controlling spending bids slightly lower for beer. There is also a positively significant effect of participants' beliefs about the cost of the products captured by the variable "Belief". A participant who believes that expensive coffee costs more also bids slightly more for expensive coffee. The same applies for coffee.

It is worth noting that 23 percent of the participants carried no cash on them at the time of the experiment and 65 percent carried less than 100. Thus, cash-on-hand constraints could indeed have affected bids had we not controlled for this. Also, the participants are highly familiar with using debit cards: the median of participants' share of transactions with debit cards is 90 percent, for cash it is only 5 percent.

\section{Discussion}


The way money is represented clearly influences consumers' willingness to pay for identical products. While the differential effect on spending and consumption caused by the payment method has been studied before using credit cards (Feinberg, 1986; Hafalir and Loewenstein, 2009; Prelec and Simester, 2001), gift certificates (Raghubir and Srivastava, 2008), pre-paid cards (Soman, 2003), and cash denominations (Mishra et al., 2006; Raghubir and Srivastava, 2009; Vandoros, 2013), this effect has not been addressed comparing debit card and cash. This is surprising since debit cards are, in terms of transactions, the most common non-cash payment instrument in many countries (CPSS, 2013). This paper fills the empirical gap in this line of payment research.

Apart from being ubiquitous, debit card transactions are also immediate. While it is easy to argue that the temporal separation of payment and consumption may be driving the results in the credit cards studies, we control for this by comparing debit cards with cash. In addition, debit cards are not restricted to certain purchases, which means that money not spent for one purchase can be freely used at other locations and for other purchases. This makes debit cards similar to cash apart from format and there is empirical evidence that people tend to treat them as substitutes for cash (Borzekowski and Kiser, 2008).

Another reason for why valuations may be lower when paying with cash is simply that participants may not be carrying enough cash and are reluctant to incur the cost of going to the ATM if they wish to spend more. In particular, in Prelec and Simester (2001) and Hafalir and Loewenstein (2009) where participants use their own funds when they pay for the products they buy, this effect may be present. Similarly in Soetevent (2011), it is possible that households donate what loose change they have available when approached by the fund raiser. Our experimental set-up controls for cash-on-hand constraints, by offering the participants 100 DKK for their participation,, price familiarity and consumption habits of the products, which are additional factors that may explain why differences could occur. Our 
results remain robust to controlling for these factors. The results thus suggest that the format of money matters and support the explanation that the transparency of the payment method affects consumer willingness to pay.

When we change the way we remunerate participants by transferring the money via PayPal, we find no differences between the willingness to pay to the cash treatment. We suggest that this is due to an earmarking effect (Hundsdoerfer et al., 2011; Prelec and Loewenstein, 1998; Sælen and Kallbekken, 2011) and thus a consequence of the experimental design $^{7}$. The reason we included the PayPal transfer treatment was that we wished to learn whether simply showing cash when paying with card would depress bids. It is possible that such an association effect is present but that it is much smaller than the earmarking effect. Considering the vast number of payment methods available today where consumers can choose between several payment methods either in their physical wallet and/or in their smart phones, separating the effect that one payment method, such as cash, could have on another payment method, such as a debit or credit card, is an avenue for future research.

The reason for not including a cash/account treatment, which would be the natural comparison group to minimize differences due to earmarking, was that we wanted to control for these cash-on-hand constraints, which was not controlled for in previous studies. We do find that most of the participants had less than 100 DKK on their person at the time of the experiment suggesting our results could indeed have been driven by cash-on-hand constraints had we not controlled for this.

The low amount of cash that our participants carried at the time of the experiment is also noteworthy for another reason. Cash as used in everyday transactions for the generation included in our study seem to be of little importance. The habits of new generations of payers,

\footnotetext{
${ }^{7}$ There are of other plausible explanations for the result. One is the unfamiliarity of being paid though PayPal, which might have created an uncertainty whether they would receive the money or not. All the participants had a PayPal account.
} 
in light of the increasing volume of transactions over the Internet suggest that future research could address the use of new and old non-cash payment methods and spending over Internet. Such comparisons could include, for example, differences between using credit or debit cards and using Internet banking when shopping online. Internet banking works similar to using cash. The amount of money to spend is clearly visible and the amount deducted shows up immediately after a payment using Internet banking. We suggest that future payment research include or at least control for two factors:

The first factor is the context of the payment situation, which could influence how we choose to pay and how much we are willing to pay. This could vary on multiple dimensions, including the time of the day (when) and the location where the payment is carried out (where - street, event, store, restaurant, home). An extreme example would be 3.00 $\mathrm{AM}$ on the street.

The second factor is the underlying payment instrument (cash, debit card, credit card, direct debits, direct credits, and e-money) and the access technology (plastic card, mobile phone, Near Field Communication (NFC), QR-codes, Internet-bank etc). It is important that we clear of what type of payment instrument and the type of access technology. For instance, in studies you often find terms such as mobile payment, without any reference to the underlying payment instrument, see please (Kokkola, 2010) for definitions of payment instruments. The payment instrument determines the processing and settlement of the payment.

\subsection{Implications}

There are several practical implications both for consumers, merchants, payment service providers and society, with the ongoing digitization of payments. First is that consumer loose some control over their spending. Payment with cash is salient as consumers see how much that is deducted from the available sum when they pay. When paying with, for 
instance debit cards or credit cards, there is no such feedback mechanism automatically included in the payment instrument. Consequently, there may be a need to develop feedback mechanisms, such as feedback on transactions and the available funds. This could be operationalized partly through text messages on mobile phones or in displays in next generation of payment card. Second, merchants have a clear incitement to promote none-cash payment, since it might induce more spending from the customers, which could lead to higher revenues. Another argument is that cash is much more expensive to manage for merchants (Garcia-Swartz et al., 2006) and such expense is expected to increase further (Nationalbanken, 2014). Third, for existing payment service providers there are a challenge to meet the requirements of the consumers and the merchants, which may be in conflict. Forth, the payment landscape and market is radically changing, and this change needs to be considered by societies, such as countries or regions. For instance, the payment market is today regulated on a national level, but payment occurs on global scale.

\section{Conclusions}

The present study investigated the difference in people’s willingness to pay between two frequently used payment instruments, namely cash and debit cards. The result shows that people are willing to pay more for identical products with debit cards than with cash. We suggest that this is because of the representation of money, leading to salience of the physical form and the salience of the amount paid with the card. The findings suggest that the format of money matters and that one rationale for why cash is still widely used, despite the desire to reduce the costly use of cash in society (Bergman et al., 2008), is that cash makes it easier to control spending and this effect cannot solely be attributed to cash-on-hand constraints. This study complements the existing research on credit cards, gift certificates and pre-paid cards by 
using debit cards which are physically different from cash but just as cash are both ubiquitous and involve immediate transactions.

\section{Appendix.1 Experiment Instructions}

The following instructions were given to the participants with treatment specific text in brackets. The treatment they belonged to (in italics) was not shown to the participants.

\section{Information about the study}

This study consists of two parts where you will make decisions and answer questions. The purpose of the study is to gain a deeper understanding of consumer behavior. Your answers will only be used for research purposes and will be kept strictly confidential.

[Cash treatment: For your participation, you will receive $100 \mathrm{kr}$ in cash. You will also be given an opportunity to purchase three products.]

[Card/cash treatment: For your participation, you will receive $100 \mathrm{kr}$ in cash. You will also be given an opportunity to purchase three products. For this purpose you will need a Dankort or VISA Electron.]

[Card/account treatment: For your participation, you will receive $100 \mathrm{kr}$ that will be transferred to you via PayPal. You will also be given an opportunity to purchase three products. For this purpose you will need a Dankort or VISA Electron.]

Please read the instructions carefully.

It is important to remain silent during the study. If you have any questions, please raise your hand.

Thank you for your participation!

Instructions for the auction.

In this part, we would like you to make bids for the following three items, A, B and C. You then have the chance to purchase one of them based on your bids.
A) A clip card for 10 beers at the Scrollbar
B) A clip card for 6 coffees at Analog café (the full selection of coffees)
C) A clip card for 12 coffees at Analog café (only black coffee) 
For each item, A, B, and C, there will be one buyer. To select who buys an item we will collect all participants' bids and for each item we will use the following procedure:

Step 1: We randomly draw a sale price for the item between 0 and 100 (all numbers are equally probable).

Step 2: We randomly draw one of all participants' bids and compare this bid with the sale price from Step 1.

- If the participant's bid is the same or higher than the sale price, the participant purchases the item at the sale price.

- If the participant's bid is lower than the sale price, there is no purchase and we draw a new sale price and a new participant's bid until there is a purchase.

Once you have made a purchase, you will not be part of the draws for the remaining items.

You can bid at most $100 \mathrm{kr}$ for each item.

[Cash treatment: The buyer pays for the item with cash after the draw.]

[Card/cash and Card/account treatments: The buyer pays for the item with card (Dankort or VISA Electron) after the draw.]

Bid sheet for the products

Please write down your bids:

For the 10 beer clip card, I bid: ___ $\mathrm{kr}$

For the 6 coffee clip card, I bid: ___ $\mathrm{kr}$

For the 12 coffee clip card, I bid: ___

\section{References}

Arvidsson, N., Markendahl, J., 2014. International Cashless Society Roundtable (ICSR), Stockholm.

Becker, G.M., DeGroot, M.H., Marschak, J., 1964. Measuring utility by a single- response sequential method. Behavioral science 9, 226-232. 
Bergman, M., Guibourg, G., Segendorf, B., 2008. Card and cash payments from a social perspective. Economici Review 2, 42-59.

Borzekowski, R., Elizabeth, K.K., Shaista, A., 2008. Consumers' use of debit cards: patterns, preferences, and price response. Journal of Money, Credit and Banking 40, 149-172.

Borzekowski, R., Kiser, E.K., 2008. The choice at the checkout: Quantifying demand across payment instruments. International Journal of Industrial Organization 26, 889-902.

Carow, K.A., Staten, M.E., 1999. Debit, credit, or cash: Survey evidence on gasoline purchases. Journal of Economics and Business 51, 409-421.

Carton, F., Hedman, J., 2013. Proceedings: Second Internationael Cashless Society Roundtable (ICSR). Financial Services Innovation Centre.

Chatterjee, P., Rose, R.L., 2012. Do Payment Mechanisms Change the Way Consumers Perceive Products? Journal of Consumer Research 38, 1129-1139.

CPSS, 2013. Statistics on payment, clearing and settlement systems in the CPSS countries: Figures for 2012. Bank for International Settlements.

Dahlberg, T., Mallat, N., Ondrus, J., Zmijewska, A., 2008. Past, present and future of mobile payments research: A literature review. Electronic Commerce Research and Applications 7, 165-181.

Del Boca, D., Flinn, C.J., 1994. Expenditure decisions of divorced mothers and income composition. Journal of Human Resources 29, 742-761.

Evans, D.S., Schmalensee, R., 2005. Paying with plastic: the digital revolution in buying and borrowing. MIT Press, Cambridge, MA.

Feinberg, R.A., 1986. Credit cards as spending facilitating stimuli: A conditioning interpretation. Journal of Consumer Research 13, 348-356.

Felső, F.Á., Soetevent, A.R., 2014. Broad and narrow bracketing in gift certificate spending. European Economic Review 66, 284-302.

Garcia-Swartz, D., Hahn, R., Layne-Farrar, A., 2006. The move toward a cashless society: a closer look at payment instrument economics. Review of Network Economics 5, 175-197.

Garcia-Swartz, D.D., Hahn, R.W., Layne-Farrar, A., 2004. The economics of a cashless society: an analysis of the costs and benefits of payment instruments. AEI-Brookings Joint Center for Regulatory Studies.

Gneezy, A., Gneezy, U., Nelson, L.D., Brown, A., 2010. Shared social responsibility: A field experiment in pay-what-you-want pricing and charitable giving. Science 329, 325327.

Hafalir, E.I., Loewenstein, G., 2009. The impact of credit cards on spending: a field experiment. SSRN eLibrary.

Haws, K.L., Bearden, W.O., Nenkov, G.Y., 2012. Consumer spending self-control effectiveness and outcome elaboration prompts. Journal of the Academy of Marketing Science 40, 695-710.

Hedman, J., 2012. Proceedings First International Cashless Society Roundtable (ICSR). Copenhagen Finance IT Region, Copenhagen, Denmark, April 18 \& 19.

Hirschman, E.C., 1979. Differences in Consumer Purchase Behavior by Credit Card Payment System. Journal of Consumer Research 6, 58-66.

Hirschman, E.C., 1982. Consumer payment systems: the relationship of attribute structure to preference and usage. Journal of Business 55, 531-545.

Holmström, J., Stalder, F., 2001. Drifting technologies and multi-purpose networks: the case of the Swedish cashcard. Information and Organization 11, 187-206.

Humphrey, D.B., 2004. Replacement of cash by cards in US consumer payments. Journal of Economics and Business 56, 211-225.

Humphrey, D.B., 2010. Retail payments: New contributions, empirical results, and unanswered questions. Journal of Banking \& Finance 34, 1729-1737.

Hundsdoerfer, J., Sielaff, C., Blaufus, K., Kiesewetter, D., Weimann, J., 2011. The influence of tax labeling and tax earmarking on the willingness to contribute: A conjoint analysis. Arqus-Diskussionsbeiträge zur quantitativen Steuerlehre.

Jonker, N., 2007. Payment instruments as perceived by consumers - Results from a household survey. Economist-Netherlands 155, 271-303.

Jung, M.H., Nelson, L.D., Gneezy, A., Gneezy, U., Paying More When Paying for Others. Journal of Personality and Social Psychology 107, 414-431. 
Kahneman, D., Knetsch, J.L., 1992. Valuing public goods: the purchase of moral satisfaction. Journal of environmental economics and management 22, 57-70.

Kokkola, T., 2010. The payment system. European Central Bank, Frankfurt am Main.

Kooreman, P., 2000. The labeling effect of a child benefit system. American Economic Review 90, 571-583.

Mallat, N., 2007. Exploring consumer adoption of mobile payments: A qualitative study. The Journal of Strategic Information Systems 16, 413-432.

Menon, G., Raghubir, P., Schwarz, N., 1997. How much will I spend? Factors affecting consumers' estimates of future expense. Journal of Consumer Psychology 6, 141164.

Mishra, H., Mishra, A., Nayakankuppam, D., 2006. Money: A bias for the whole. Journal of Consumer Research 32, 541-549.

Nationalbanken, 2014. Report on new payment solutions, Copenhagen.

Ondrus, J., Pigneur, Y., 2006. Towards a holistic analysis of mobile payments: a multiple perspectives approach. Electronic Commerce Research and Applications 5, 246-257.

Plouffe, C.R., Hulland, J.S., Vandenbosch, M., 2001. Research report: Richness versus parsimony in modeling technology adoption decisions-understanding merchant adoption of a smart card-based payment system. Information Systems Research 12, 208-222.

Prelec, D., Loewenstein, G., 1998. The red and the black: Mental accounting of savings and debt. Marketing Science 17, 4-28.

Prelec, D., Simester, D., 2001. Always leave home without it: A further investigation of the credit-card effect on willingness to pay. Marketing letters 12, 5-12.

Raghubir, P., 2006. An information processing review of the subjective value of money and prices. Journal of Business Research 59, 1053-1062.

Raghubir, P., Srivastava, J., 2002. Effect of face value on product valuation in foreign currencies. Journal of Consumer Research 29, 335-347.

Raghubir, P., Srivastava, J., 2008. Monopoly money: The effect of payment coupling and form on spending behavior. Journal of Experimental Psychology-Applied 14, 213225.

Raghubir, P., Srivastava, J., 2009. The denomination effect. Journal of Consumer Research 36, 701-713.

Rick, S.I., Cryder, C.E., Loewenstein, G., 2008. Tightwads and spendthrifts. Journal of Consumer Research 34, 767-782.

Sælen, H., Kallbekken, S., 2011. A choice experiment on fuel taxation and earmarking in Norway. Ecological Economics 70, 2181-2190.

Schierz, P.G., Schilke, O., Wirtz, B.W., 2010. Understanding consumer acceptance of mobile payment services: An empirical analysis. Electronic Commerce Research and Applications 9, 209-216.

Slawsky, J.H., Zafar, S., 2005. Developing and Managing a Successful Payment Cards Business. Gower Publishing, Ltd.

Soetevent, A.R., 2011. Payment choice, image motivation and contributions to charity: evidence from a field experiment. American Economic Journal: Economic Policy 3, 180-205.

Soman, D., 2001. Effects of payment mechanism on spending behavior: The role of rehearsal and immediacy of payments. Journal of Consumer Research 27, 460-474.

Soman, D., 2003. The effect of payment transparency on consumption: Quasi-experiments from the field. Marketing Letters 14, 173-183.

Srivastava, J., Raghubir, P., 2002. Debiasing using decomposition: The case of memory-based credit card expense estimates. Journal of Consumer Psychology 12, 253-264.

Thomas, M., Desai, K.K., Seenivasan, S., 2011. How credit card payments increase unhealthy food purchases: visceral regulation of vices. Journal of consumer research 38, 126139.

Vandoros, S., 2013. My five pounds are not as good as yours, so I will spend them. Experimental economics 16, 546-559.

Worthington, S., Stewart, D., Lu, X., 2007. The adoption and usage of credit cards by urbanaffluent consumers in China. International Journal of Bank Marketing 25, 238-252. 
Xin, H., Techatassanasoontorn, A.A., Tan, F.B., forthcomming. Antecedents of consumer trust in mobile payment adoption. Journal of Computer Information System.

Zinman, J., 2009. Debit or credit? Journal of Banking \& Finance 33, 358-366.

Zwass, V., 1996. Electronic commerce: structures and issues. International Journal of Electronic Commerce 1, 3-23. 
C

\section{Information about the study}

This study consists of two parts where you will make decisions and answer questions. The purpose of the study is to gain a deeper understanding of consumer behavior. Your answers will only be used for research purposes and will be kept strictly confidential.

For your participation, you will receive $100 \mathrm{kr}$ in cash. You will also be given an opportunity to purchase three products.

Please read the instructions carefully.

It is important to remain silent during the study. If you have any questions, please raise your hand.

Thank you for your participation!

Emma Svensson

Jonas Hedman

If you have any queries, please contact Emma Svensson at es.itm@cbs.dk. 
State the letters on your ID-card:

In this part, we would like you to make bids for the following three items, A, B and C. You then have the chance to purchase one of them based on your bids.
A) A clip card for 10 beers at the Scrollbar
B) A clip card for 6 coffees at Analog café (the full selection of coffees)
C) A clip card for 12 coffees at Analog café (only black coffee)

For each item, A, B, and C, there will be one buyer. To select who buys an item we will collect all participants' bids and for each item we will use the following procedure:

Step 1: We randomly draw a sale price for the item between 0 and 100 (all numbers are equally probable).

Step 2: We randomly draw one of all participants' bids and compare this bid with the sale price from Step 1.

- If the participant's bid is the same or higher than the sale price, the participant purchases the item at the sale price.

- If the participant's bid is lower than the sale price, there is no purchase and we draw a new sale price and a new participant's bid until there is a purchase.

Once you have made a purchase, you will not be part of the draws for the remaining items.

You can bid at most $100 \mathrm{kr}$ for each item.

The buyer pays for the item with cash after the draw. 
Before you make your bids, we would like you to answer the following questions:

1) What is the maximum amount you can bid for item A? $\mathrm{kr}$

2a) Which of the following is correct: If your bid is chosen and the purchase takes place

I pay the amount I have bid for the item:

I pay the sale price you have drawn for the item in Step 1:

2b) Assume that your bid is chosen and that it is lower than the sale price we have drawn in Step 1, can you buy the item?

Yes: $\square \quad$ No: 
State the letters on your ID-card:

Please write down your bids:

For the 10 beer clip card, I bid: $\mathrm{kr}$

For the 6 coffee clip card, I bid: $\mathrm{kr}$

For the 12 coffee clip card, I bid: $\mathrm{kr}$ 


\section{CA}

\section{Information about the study}

This study consists of two parts where you will make decisions and answer questions. The purpose of the study is to gain a deeper understanding of consumer behavior. Your answers will only be used for research purposes and will be kept strictly confidential.

For your participation, you will receive $100 \mathrm{kr}$ that will be transferred to you via PayPal. You will also be given an opportunity to purchase three products. For this purpose you will need a Dankort or VISA Electron.

Please read the instructions carefully.

It is important to remain silent during the study. If you have any questions, please raise your hand.

Thank you for your participation!

Emma Svensson

Jonas Hedman

If you have any queries, please contact Emma Svensson at es.itm@cbs.dk. 


\section{CA}

State the letters on your ID-card:

In this part, we want you to make bids for the following three items, A, B and C. You then have the chance to purchase one of them based on your bids.
A) A clip card for 10 beers at the Scrollbar
B) A clip card for 6 coffees at Analog café (the full selection of coffees)
C) A clip card for 12 coffees at Analog café (only black coffee)

For each item, A, B, and C, there will be one buyer. To select who buys an item we will collect all participants' bids and for each item we will use the following procedure:

Step 1: We randomly draw a sale price for the item between 0 and 100 (all numbers are equally probable).

Step 2: We randomly draw one of all participants' bids and compare this bid with the sale price from Step 1.

- If the participant's bid is the same or higher than the sale price, the participant purchases the item at the sale price.

- If the participant's bid is lower than the sale price, there is no purchase and we draw a new sale price and a new participant's bid until there is a purchase.

Once you have made a purchase, you will not be part of the draws for the remaining items.

You can bid at most $100 \mathrm{kr}$ for each item.

The buyer pays for the item with card (Dankort or VISA Electron) after the draw. 
Before you make your bids, we would like you to answer the following questions:

1) What is the maximum amount you can bid for item A? $\mathrm{kr}$

2a) Which of the following is correct: If your bid is chosen and the purchase takes place

I pay the amount I have bid for the item:

I pay the sale price you have drawn for the item in Step 1:

2b) Assume that your bid is chosen and that it is lower than the sale price we have drawn in Step 1, can you buy the item?

Yes: $\square \quad$ No: 
State the letters on your ID-card:

Please write down your bids:

For the 10 beer clip card, I bid: $\mathrm{kr}$

For the 6 coffee clip card, I bid: $\mathrm{kr}$

For the 12 coffee clip card, I bid: $\mathrm{kr}$ 
$\mathbf{C C}$

\section{Information about the study}

This study consists of two parts where you will make decisions and answer questions. The purpose of the study is to gain a deeper understanding of consumer behavior. Your answers will only be used for research purposes and will be kept strictly confidential.

For your participation, you will receive $100 \mathrm{kr}$ in cash. You will also be given an opportunity to purchase three products. For this purpose you will need a Dankort or VISA Electron.

Please read the instructions carefully.

It is important to remain silent during the study. If you have any questions, please raise your hand.

Thank you for your participation!

Emma Svensson

Jonas Hedman

If you have any queries, please contact Emma Svensson at es.itm@cbs.dk. 
State the letters on your ID-card:

In this part, we want you to make bids for the following three items, A, B and C. You then have the chance to purchase one of them based on your bids.
A) A clip card for 10 beers at the Scrollbar
B) A clip card for 6 coffees at Analog café (the full selection of coffees)
C) A clip card for 12 coffees at Analog café (only black coffee)

For each item, A, B, and C, there will be one buyer. To select who buys an item we will collect all participants' bids and for each item we will use the following procedure:

Step 1: We randomly draw a sale price for the item between 0 and 100 (all numbers are equally probable).

Step 2: We randomly draw one of all participants' bids and compare this bid with the sale price from Step 1.

- If the participant's bid is the same or higher than the sale price, the participant purchases the item at the sale price.

- If the participant's bid is lower than the sale price, there is no purchase and we draw a new sale price and a new participant's bid until there is a purchase.

Once you have made a purchase, you will not be part of the draws for the remaining items.

You can bid at most $100 \mathrm{kr}$ for each item.

The buyer pays for the item with card (Dankort or VISA Electron) after the draw. 
Before you make your bids, we would like you to answer the following questions:

1) What is the maximum amount you can bid for item A? $\mathrm{kr}$

2a) Which of the following is correct: If your bid is chosen and the purchase takes place

I pay the amount I have bid for the item:

I pay the sale price you have drawn for the item in Step 1:

2b) Assume that your bid is chosen and that it is lower than the sale price we have drawn in Step 1, can you buy the item?

Yes: $\square \quad$ No: 
State the letters on your ID-card:

Please write down your bids:

For the 10 beer clip card, I bid: $\mathrm{kr}$

For the 6 coffee clip card, I bid: $\mathrm{kr}$

For the 12 coffee clip card, I bid: $\mathrm{kr}$ 


\section{A}

State the letters on your ID-card:

In this part, we want you to guess how much each of the following items you have bid for costs at the point of sale at the IT University.
A) A clip card for 10 beers at the Scrollbar
B) A clip card for 6 coffees at Analog café (the full selection of coffees)
C) A clip card for 12 coffees at Analog café (only black coffee)

You can earn money on a good guess.

We will collect all the participants' answers and among these we randomly draw one participant's answers. For each item he/she has made a correct guess, he/she will receive $20 \mathrm{kr}$. For an incorrect guess, he/she will receive $0 \mathrm{kr}$.

Please make your guesses:

I think that a clip card for 10 beers at Scrollbar costs? $\mathrm{kr}$

I think that a clip card for 6 coffees at Analog costs?___ $\mathrm{kr}$

I think that a clip card for 12 coffees at Analog costs?___ $\mathrm{kr}$ 
Now we would like you to answer three questions. Please circle your choice.

1) Which of the following descriptions fits you better?

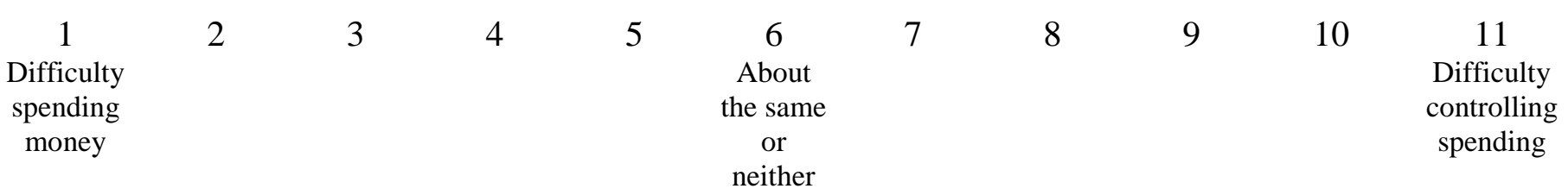

2) Description 1: Some people have trouble limiting their spending: they often spend money for example on clothes, meals, vacations, phone calls - when they would do better not to.

Description 2: Other people have trouble spending money. Perhaps because spending money makes them anxious, they often don't spend money on things they should spend it on.

a) How well does the first description fit you? That is, do you have trouble limiting your spending?

$\begin{array}{ccccc}1 & 2 & 3 & 4 & 5 \\ \text { Never } & \text { Rarely } & \text { Sometimes } & \text { Often } & \text { Always }\end{array}$

b) How well does the second description fit you? That is, do you have trouble spending money?

$\begin{array}{ccccc}1 & 2 & 3 & 4 & 5 \\ \text { Never } & \text { Rarely } & \text { Sometimes } & \text { Often } & \text { Always }\end{array}$

3) Following is a scenario describing the behavior of two shoppers. After reading about each shopper, please answer the question that follows.

Mr. A is accompanying a good friend who is on a shopping spree at a local mall. When they enter a large department store, Mr. A sees that the store has a "one-day-only-sale" where everything is priced 10-60\% off. He realizes he doesn't need anything, yet can't resist and ends up spending almost $1000 \mathrm{kr}$ on stuff.

Mr. B is accompanying a good friend who is on a shopping spree at a local mall. When they enter a large department store, Mr. B sees that the store has a "one-day-only-sale" where everything is priced 10-60\% off. He figures he can get great deals on many items that he needs, yet the thought of spending the money keeps him from buying the stuff.

In terms of your own behavior, who are you more similar to, $\mathrm{Mr}$. A or Mr. B?

$\begin{array}{cccc}1 & 2 & 3 & 4 \\ \text { Mr. A } & \begin{array}{c}\text { About the same } \\ \text { or neither }\end{array} & & \text { Mr. B }\end{array}$


In this part, we would like you to answer some questions regarding yourself.

1) Age: years

2) Gender: Man: $\square$ Woman:

3) Nationality: $\square$ Danish $\square$ Other, please specify:

4) Which program of study are you enrolled in?

5) Average monthly income after taxes:

$\square$ Up to $5000 \mathrm{kr} \quad \square 5001-10000 \mathrm{kr} \quad \square 10001-15000 \mathrm{kr} \quad \square$ More than $15000 \mathrm{kr}$

6) How many cups of coffee do you drink, on average, every day? cups

7) How many beers (bottle or pints) do you drink, on average, every week? beers

8) How many of your payment transactions are done with cash, debit or credit card, on average, each month? $\%$ cash $\%$ debit card (e.g. Dankort or VISA Electron) $\%$ credit card

9) How much cash and how many debit and credit cards are you carrying with you right now?

Cash: $\mathrm{kr}$

Number of debit cards: cards

Number of credit cards: cards 
10) Do you have PayPal? Yes: $\square$ No: $\square$

\section{Thank you for your participation!}

Please remain silent, we will soon make the final draw. 


\section{CAC}

In this part, we would like you to answer some questions regarding yourself.

1) Age: years

2) Gender: Man: $\square$ Woman:

3) Nationality: $\square$ Danish $\square$ Other, please specify:

4) Which program of study are you enrolled in?

5) Average monthly income after taxes:

$\square$ Up to $5000 \mathrm{kr} \quad \square 5001-10000 \mathrm{kr} \quad \square 10001-15000 \mathrm{kr} \quad \square$ More than $15000 \mathrm{kr}$

6) How many cups of coffee do you drink, on average, every day? cups

7) How many beers (bottle or pints) do you drink, on average, every week? beers

8) How many of your payment transactions are done with cash, debit or credit card, on average, each month? $\%$ cash $\%$ debit card (e.g. Dankort or VISA Electron) $\%$ credit card

9) How much cash and how many debit and credit cards are you carrying with you right now?

Cash: $\mathrm{kr}$

Number of debit cards: cards

Number of credit cards: cards 
10) Do you have PayPal? Yes: $\square$ No:

11a) Do you have credit from your bank connected to the card you intended to pay with in this experiment? Yes: $\square$ No:

If you answered yes to question 11a, please answer 11b, $c, d$.

11b) How much credit is attached to this account?

Up to $5000 \mathrm{kr} \quad \square 5001-10000 \mathrm{kr} \quad \square 10001-15000 \mathrm{kr} \quad \square$ More than $15000 \mathrm{kr}$

11c) Have you used any of this credit during the last month?

Yes: $\square$ No:

11d) Out of the last 12 months, how many months have you used this credit? months

\section{Thank you for your participation!}

Please remain silent, we will soon make the final draw. 